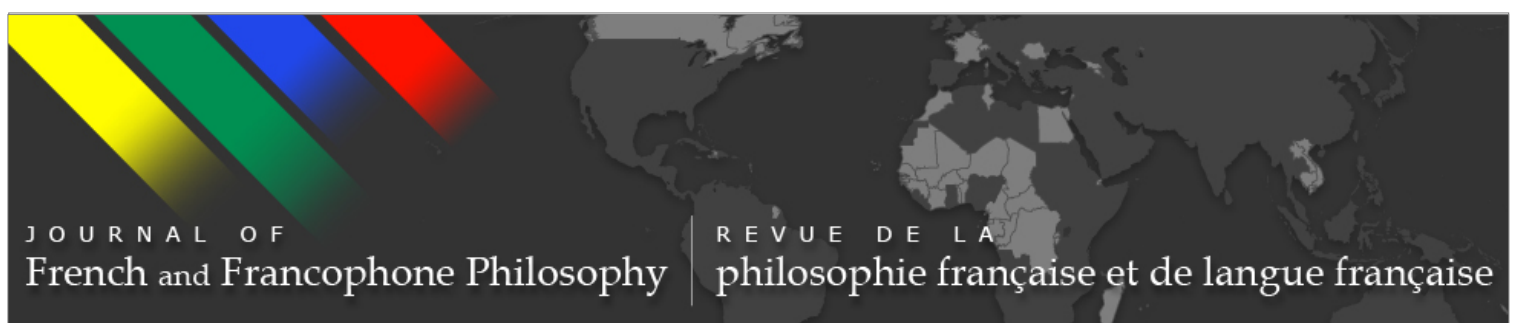

\title{
Creolizing Political Institutions
}

Jane Anna Gordon

Journal of French and Francophone Philosophy - Revue de la philosophie française et de langue française, Vol XXV, No 2 (2017) pp 54-66.

\author{
Vol XXV, No 2 (2017) \\ ISSN 1936-6280 (print) \\ ISSN 2155-1162 (online) \\ DOI 10.5195/jffp.2017.825 \\ www.jffp.org
}

\section{(c) ) EY-NC-ND}

This work is licensed under a Creative Commons Attribution-Noncommercial-No Derivative Works 3.0 United States License.

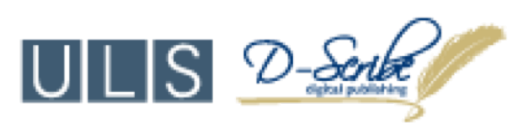

This journal is operated by the University Library System of the University of Pittsburgh as part of its D-Scribe Digital Publishing Program, and is co-sponsored by the University of Pittsburgh Press 


\title{
Creolizing Political Institutions
}

\author{
Jane Anna Gordon \\ UCONN-Storrs
}

When completing the manuscript that became Creolizing Political Theory, I thought I had written what I had to say on this theme and would therefore turn to other, for me, new and distinct projects. ${ }^{1}$ As I began actually to undertake them, however, I realized that if the whole point of creolizing were that it is a living manifestation of rigorous thinking, trying to leave it behind would be a mistake.

This was clear first when developing a course focused on Historical Women Political Thinkers. Using Lewis Gordon's Introduction to Africana Philosophy as a model, I wanted to see if unique themes emerged as women wrote about and argued for their substantive inclusion in political life, as had been the case when black writers across the Euromodern world undertook philosophical reflection. ${ }^{2}$ Without the lens of creolization, I likely would have determined the selection of figures and texts quite differently. My primary interest was in looking at any and all works I could identify, but especially those that long pre-dated contemporary Euro-American feminist theory. As Penny Weiss observed, they exist in wonderful abundance, with origins across centuries and the globe. ${ }^{3}$ I assumed that how being female informed political reflection would be expressed very differently in the hands of a $15^{\text {th }}$-century Italian-French self-supporting scribe turned writer, a $17^{\text {th }}$ century Ethiopian anti-colonial charismatic religious leader, an $18^{\text {th }}$-century Afro-Caribbean enslaved woman turned abolitionist activist, a $19^{\text {th }}$-century Eastern European revolutionary Marxist or Chinese anarchist, and a $20^{\text {th }}$ century Chicana. But what emerged with surprising regularity were, among other themes, grappling with the supposed illegitimacy of women as political thinkers and actors, their presumed monstrosity as they advanced conceptions of fundamentally altered ways of reproducing the human species, and concern with how distinct obligations tied to the ability to give birth informed analyses of war and other political conditions that led to premature and callous loss of life.

Similarly, in the research I am currently undertaking that explores statelessness and contemporary enslavement as core, rather than

Journal of French and Francophone Philosophy | Revue de la philosophie française et de langue française Vol XXV, No 2 (2017) | www.jffp.org | DOI 10.5195/jffp.2017.825 
aberrational features, of Euromodern political life, creolizing approaches emerged as necessary. On the matter of statelessness, it became clear that discussions of the theme undertaken among human rights scholar-activists and international lawyers had largely not been and must be put into conversation with historic and contemporary work on settler colonialism and indigenous thought and practice. Likewise, while it is indisputable that the trans-Atlantic trade racialized enslavement in ways without precedent that continue to cast a dense shadow over legally free black subjects, forced labor in the current moment combines older and newer political economic developments. This has led me to argue, against many detractors, that it is accurate to call some contemporary forms of unfreedom "slavery." This project culminates in an unapologetic effort to rethink political institutions in ways that respond directly to the anti-statism that currently abounds on the intellectual left. In short, in ways to which I will return at greater length, I contend that we must treat political institutions as creatures for which we are undoubtedly responsible and for which we must therefore fight with all of our creative resources. In so doing, I am joining scholars primarily engaged with Latin American political thought and practice, including Enrique Dussel's explorations translated into English as Twenty Theses on Politics, George Ciccariello-Maher's We Created Chavez, Katherine Gordy's Living Ideology in Cuba, and Angélica Maria Bernal's Beyond Origins. ${ }^{4}$

A central element of this challenge is illuminated by the work of Nathalie Etoke, as evident in this symposium and beyond it. ${ }^{5}$ Part of what first motivated me to read Rousseau through Africana and Francophone Africana resources was that it struck me that an actual general will-one as general as the society itself-would be incredibly difficult for advantaged members of a polity to grasp. After all, they were regularly indulged in treating their highly particular and often parochial vantage points as isomorphic with reality itself. By contrast, it was racialized-colonized residents who knew the putative ideals of the societies of which they were apart along with their ongoing and fundamental compromising. Surely it was they who were potentially better poised to work through these contradictions to fathom a better approximation of the common good. My hope was for a "better approximation" rather than a "better accomplishment" because I assumed that a feature of emancipatory political action is its incompleteness, in the sense that it brings new conditions into being. As it does so, ways of being a person emerge along with predicaments that cannot be anticipated. Additionally, as I will return to with my discussion of Kevin Bruyneel's contribution to this symposium, even progressive actors frequently reproduce what is liminal to the settler colonial societies in which they reside. As I tried to struggle through this intuition in my dissertation, I had argued that in a society like the United States, it would be political subjects with what W.E.B. Du Bois called double consciousness and Paget Henry rearticulated as potentiated double consciousness who could best articulate a general will. ${ }^{6}$ At the same time, their very ability

Journal of French and Francophone Philosophy | Revue de la philosophie française et de langue française 
to do so made it unlikely people committed to $a$ will of some masquerading as a general will would actually listen. Given the Francophone origins of the general will and the debates that were then raging over the permissibility of wearing hijabs in public spaces, especially in schools, I reached similar conclusions regarding that situation. In short, it was so clearly wrong that Muslim and non-Muslim African-descended French subjects, in seeking to be part of the French Republic, were framed as divisive, sullying, through their identitarianism or assertion of cultural backwardness, an otherwise vital general will. Instead, an actual general will, as opposed to a will of a select few of the French Republic, had to grapple with what they and these subjects, likely to be in the vanguard of such political reflection, shared.

The contemporary French leaders, as Nathalie Etoke observes, who, without any sense of irony, declare that France now seeks to turn inward, away from its previously imperial orientation, should be visited by the ghost of Aimé Césaire. ${ }^{7}$ He would remind them that a distinctive feature of European political history and culture was its claimed ability to insulate itself from what transpired in its colonies. This was as evident in the claim that mere contact with French or English soil turned the slave into a free man or woman as that the callous brutality unleashed in the Caribbean and in Africa was the work of creoles, not French- or Englishmen. In fact, Césaire insisted, it was Europeans who were "settling" thoroughly occupied polities in the Americas, Africa, and Asia through torture, dispossession, and murder. Meanwhile, it was their counterparts in mainland, continental Europe who stomached this as acceptable Christian, European, and civilizing policy. But Césaire's point wasn't simply to engage in moral criticism. The aim was historical diagnosis: the transformations to the colonizers produced by their colonial endeavors returned home with them. It was not true that they could practice democracy at home and fascism abroad, for they returned with their sensibilities and characteristics. The implications were that what transpired as the supposedly extreme and exceptional events of the holocaust were nothing more than colonial policy returned home as domestic practice, colonial policy unleashed on fellow Europeans. We are in a similar moment now. With a globe made smaller by technologies that accelerate the speed of movement of people, goods, and ideas, the physical and psychic distance that Europe maintained from its colonies is collapsing. The moment exemplifies Patrick Wolfe's claim that practices of racialization or of racist violence intensify as colonizers are forced to share what they consider their spaces with the people they have colonized. ${ }^{8}$ In short, the French leadership quoted by Etoke would rather hollow out the French state, ever narrowing the nation to which it refers and how they should thereby benefit, than having it embody the actual range of people and processes that generated its current form. Etoke underscores the especially stark irony of the French case. After all, it is no accident that the Francophone world is at the center of studies and debates over creolization. French and Francophone scholars authored most of its central terms and

Journal of French and Francophone Philosophy | Revue de la philosophie française et de langue française

Vol XXV, No 2 (2017) | http://www.jffp.org | DOI 10.5195/jffp.2017.825 
texts. Still, or for precisely this reason, as French-speaking African peoples come to the metropole seeking a polity and political institutions that reflect the Francophone world's actual constitution, they are told not only that they are extraneous, but also that their presence is illicit. They exemplify the distinction between assimilation and creolization. If the former were an option, these Francophone subjects could become French by ceasing to be who they are. Creolization charts an alter-native (a linguistic move made by Sandy Grande) that does not leave such a singularly violent and exclusionary standard intact. ${ }^{9}$

Creolizing French political institutions and identities would have to resemble Etoke's own explorations in film that bring together different modes of analysis-those expressed in literature, philosophy, and song-to convey what it is to resist being cast into the zone of nonbeing. ${ }^{10}$ In so doing, Etoke affirms, as Jean-Jacques Rousseau and Frantz Fanon, among many others, so compellingly argued, the production of knowledge cannot be disentangled from the colonial world of which it is part. What will be prized and treated as authoritative, after all, is not generated in a vacuum. Although academic and intellectual spaces are internally complex ones in which varieties of projects are undertaken, what Kevin Bruyneel calls "settler memory" organizes and prioritizes hegemonic accounts of what is worth knowing. At the same time, as Bruyneel illustrates, the actual history of the United States (or Canada or France) is far more creolized than the ways in which it is mobilized ideologically as memory.

What then would it mean for collective U.S. memory (or how history is marshalled in the political arena) to better reflect our actual past? As Bruyneel explores through critical engagement with W.E.B. Du Bois's magnificent Black Reconstruction, it would certainly feature Americans (or Canadians or the French) revisiting particularly pivotal or foundational moments in their past, for example, in the U.S. case, the Civil War and Reconstruction. $^{11}$ They would, as Du Bois does, challenge standard depictions of who and what had propelled these conflicts, how they unfolded, and what did not but might have transpired. With Du Bois, it was the general strike of black people refusing to continue to work and then stealing themselves from plantations who while thought not to be political actors in fact altered the course and nature of the events of what many Southerners still call "the Northern War of Aggression." In the short period that followed, in an effort to eradicate their enslavement, black people pushed for and inhabited institutions that could have reconstructed the entire, not only the black, South into something actually resembling a democratic republic. At the same time, as Bruyneel astutely emphasizes, Du Bois and historical and contemporary figures who share his political sensibilities could further creolize their creolizing account. After all, what $\mathrm{Du}$ Bois celebrates as a splendid failure occurs simultaneously with the Sioux Nation's successful effort to force the U.S. government into a peace

Journal of French and Francophone Philosophy | Revue de la philosophie française et de langue française Vol XXV, No 2 (2017) | http://www.jffp.org | DOI 10.5195/jffp.2017.825 
agreement that legally recognized their claim to territory. To engage in this more rigorous creolizing, they would have to pay due attention to the subjects and stories that remain liminal in their account, or those appearing only through their absent presence. More specifically, when discussing the relationship between ownership and political belonging, Du Bois mirrors, rather than challenges, the contours of settler memory. Rather than creolizing abolitionist and decolonizing approaches, he fails to connect how the land used to create the plantation South was "cleared" through forced removal of its original occupants. Similarly, his exploration of the unfulfilled promise of forty acres and a mule did not tie questions of expropriated labor to those of land dispossession and therefore could not consider whether forging an American present and future that better embodies a creolizing and therefore generalizing will would have to break fundamentally from conceptions of political standing tied to individualized private property rooted in the extraction of soil from America's original occupants. These shortcomings are in ample display in the depictions of native peoples Keisha Lindsay and I have traced in the writings of $18^{\text {th }}$-and $19^{\text {th }}$-century New World black writers seeking to make a case for their own rightful place in the emergent U.S. nation. ${ }^{12}$

Bruyneel's reflections in this symposium are tied to larger ones that he is undertaking along with Glen Sean Coulthard in the spirit of Patrick Wolfe, Vine Deloria Jr., and George Manuel and Michael Posluns on the relationship of the "black" to the "red." 13 In exactly the way that creolizing analysis should unfold, the forging of solidarity requires first disentangling and then engaging with the historical consequences of the specific, discrete, and complementary workings of settler colonialism. For instance, if the aim with African-descended peoples in the U.S. was to extract labor indispensable to national development while radically segregating such people from ever actually forming part of the nation to which the state referred, the goal with native peoples was evacuation. For this reason, if Indians were first repeatedly "removed" beyond white borders, when they were territorially engulfed, they were to be made extinct through their assimilation or de-Indianizing. For Deloria, while many black Americans sought full incorporation and membership in the U.S. polity through the initial stage of the Civil Rights movement, their Indian counterparts, in ways that resonated better with the nationalism of the Black Power movement, wanted to be left alone or outside the coercive embrace of the U.S. state. In Manuel and Posluns, the fourth world that would emerge with aboriginal peoples globally anticipated the Zapatista idea of a world in which many worlds fit. Inspired by revolutionary efforts in Tanzania to create a modern nation on a model distinct from those of Europe, it was to be one in which new technologies borne of human creativity could be used to express older values that prized the conditions of our continued existence over that which is novel or new. Crucially, for Manuel and Posluns, the desire to withdraw from the orbit of illegitimate occupying governments had nothing to do with

Journal of French and Francophone Philosophy | Revue de la philosophie française et de langue française

Vol XXV, No 2 (2017) | http://www.jffp.org | DOI 10.5195/jffp.2017.825 
an impulse to be culturally pure or unchanging. Quite the opposite. As they argued so beautifully: cherishing a relationship with the land does not require continuing to use a wooden plough. Indeed, they celebrated distinct ideas that emerged from the shared situation of being aboriginal. They included in that category both those of whom they and other indigenous Canadians were aware (among them, the Maori, the Lapp, and the Welsh) and those whom they would still come to know. In other words, the creolization that could and would still emerge required the deliberate rejection of political systems premised upon avowed decreolization. In this way, Manuel and Posluns's analysis also shares much in common with Fanon, for whom the aim of colonization is to create a world of contraries or opposed, mutually exclusive universals that would not meet in relation. Through struggle against institutions that sought to make them real, contraries were turned into contradictions through which creolizing processes could and did unfold. In an older and more European-specific rendition of a similar point, Rousseau had argued that one could not forge a general will between people who thought all others were damned and the supposedly damned or between those who enriched themselves through immiserating others and the immiserated. In each such instance, since the self-conception of the former was premised on being outside of relations with the others who constituted the majority of the relevant whole, they had to be resisted for vital political alternatives to emerge.

Even if a revolutionary people can embody such creolizing relations, Michael Neocosmos asks whether these can be institutionalized or routinized in ways that do not banish a mobilized people into passivity. Neocosmos's answer appears to be no. This is what states are. This is what states do. We should therefore celebrate what are episodic moments of mass movements that generate concepts and experiences that exceed conditions and thinking that precedes and will follow them. Neocosmos does also offer the longer running model of the Haitian bossales who, within the technical orbit of a state, resisted its grasp and thereby its crushing logics. However, if politics, as Neocosmos describes it, cannot be extended to suffuse the conditions of ongoing, mundane life, how are we to understand its actual reach? Is it that, in fleeting moments, people cohere around shared political commitments regardless of their differential situations and can then recall this when the mobilization has passed? Or is it that self-governance can only continue where a decision is made to operate in the shadows of the predominant state system, not offering an offensive counter to it but operating in a refuge?

Put differently, Neocosmos has made a highly compelling case for the indispensability of dialectical thinking and approaches to politics with which I could not agree more. At the same time, it is clear that Neocosmos and I have different responses to the question of whether there can be legitimate political institutions. In Neocosmos's account, emancipatory 
popular politics emerges in moments that must be finite. Efforts to translate these into state power, even when the leaders themselves are borne of this movement, inevitably collapse into a representative politics that sends the mobilized people back into the caves or into political passivity. Indeed, the newly instated, time and time again, retrench in direct proportion to the capaciousness of what generated them. This is not due to Max Weber's concern with the routinization of charisma. Instead the point is Rousseauian: popular sovereignty cannot be divided or represented. Failure to grasp this, for Neocosmos, leads Fanon into a mistaken view that frames the national bourgeoisie and its one-party state as a problem external to an otherwise revolutionary movement. For Neocosmos, Fanon is wrong to frame these actors as having hijacked and betrayed what otherwise might have been, if the implications are that there could have been any people who or party that would have acted differently. This is because it is an error, for Neocosmos, to treat revolutionary moments as something that can be made to endure, or as a transitional precursor transformed meaningfully into state power. At the same time, in his view, what transpires in those fleeting moments is not an approximation of a general will or a common good or a mobilized people or national consciousness. These are achieved and those involved experience this process of becoming.

Even as Rousseau described "the people" as dying from the moment of their inception and criticized governments as creating problems for the pursuit of the general will, he both described formerly colonized (Corsican) people whose general wills were still emergent and bothered to author a full-fledged portrait of a polity. The text was replete with doubt and qualification, revealing more about profoundly misleading conceptions of liberty than confidence in the models he delineated. But if emancipatory politics is not a narrow politics of experience, surely we do have to tend to better and worse ways of facilitating its extension. Without discussion of institutionalization, such emancipatory events would appear to collapse into the kind of regulative ideals that Neocosmos associates with the limits of analytical thought: they would enable us to affirm that another world is possible since, for a fleeting moment, we witnessed and knew it.

For most participants who undertake such activity at great risk, the exhilaration of the moment is not primarily a matter of being unburdened by divisive identities unleashed from the seismic weight of the colonial past and more about creating the conditions of a less compromised freedom and of fuller self-determination and dignity. Their politics, then, is not only about a collective subject mobilized in pursuit of the common good but the series of actions that set in motion expanded options for those doing the struggling. When the mobilization that cannot endure has come to an end, they should return to functional homes and clean water and excellent schools and a reprieve from state violence.

Journal of French and Francophone Philosophy | Revue de la philosophie française et de langue française Vol XXV, No 2 (2017) | http://www.jffp.org | DOI 10.5195/jffp.2017.825 
It is true that Fanon devoted more time to diagnosing what was wrong with the national bourgeoisie than the kinds of institutions that he thought could give continued expression to national consciousness. At the same time, he did offer some guidance. It came in his emphasis on assuring that it was citizens who undertook collective decision-making and planning. It was evident in his urging to refuse the hiring of foreign expertise if this would stall opportunities and divert resources that could be used to develop local skilled labor. Efficient solutions were to be eschewed if they did not extend the political thinking of the people as a whole. These comments are reminiscent of Rousseau's efforts to envision how a sovereign people could continue to be self-legislating. Logistical considerations had to follow more primary commitments, even if this required, as was supposedly the case in the Roman republic, citizens participating from the rooftops. There were also Fanon's cautions against collapsing into colonial divides between urban elites and rural majorities and his push to have, instead of a fixed political capital, one that moved throughout the physical territory of the nation. When he argues that those seeking to govern themselves should not just adopt a capitalist or Soviet model of economy and that each generation must live up to its mission, the message was that physically ousting settlers was not sufficient. Revolutionary struggle meant transforming the society from the bottom up, guided by a national consciousness that would transmute anti-colonial nationalism into a way of organizing a society for all, especially the nobodies.

If we take Fanon's sociogenetic diagnosis and argument seriously, then, it must extend to political institutions or to the potential meaning of the state. Just as these have changed their nature across time, they can still be altered. Or, we may not have exhausted their potential forms. Peopled by human beings, it is they or we who must make them run and who are thereby responsible for their character. We therefore cannot treat them with existential seriousness or as features of an unchanging natural world. If the specific concern is with how institutionalizing power and decision-making banishes collective agency, then that is the challenge to which our designs must directly respond. But to treat all political institutions as if they amount to the flawed, antipolitical, and illegitimate same is to fail to heed Lewis Gordon's analysis of Fanon's challenge to the anti-statism of Friedrich Engels. $^{14}$

One central difference in Neocosmos and my reading of Rousseau is technical. Rousseau hated cosmopolitan politics and any other forms that tended, as Julia Suárez-Krabbe diagnoses, to mistake the internationalizing of a particular idea or practice for its inherent universalism. ${ }^{15}$ For Rousseau, polities, political identities, and political wills aimed to be general, consisting in what meaningful differences had in common. There were generalities that were narrower-so government officials shared a general will tied to their professional location rather than the society itself-and this often made

Journal of French and Francophone Philosophy | Revue de la philosophie française et de langue française Vol XXV, No 2 (2017) | http://www.jffp.org | DOI 10.5195/jffp.2017.825 
them obstacles to the pursuit of an actual general will. At the same time, what mediate the particular and universal and could last, even if it remained fragile and prone to abuse and muting, were generality and the general will. This informs my own view of the relationship between generalizing and creolizing. While it is true that narrow identitatarianism is dislodged by arrays of people who share political commitments that seek an enlarged common good, this does not involve a transcendence of identity altogether. What emerges instead is a way of expressing who and what it is to be Algerian or South African or American that is organically tied to what is local while being open to contributing sources that always exceed narrowing hegemonic accounts of the relevant nations. Loving the land does not require wielding a wooden plough.

Rousseau and Fanon are exemplary figures for exploring the idea of creolization, as Neocosmos states, because of how fundamentally dialectical their thinking was. As Neocosmos describes it, they break fundamentally from analytical thought, demanding that we think beyond what we can experience or have known. In Rousseau's view, skepticism toward such an approach, which prevailed and prevails, is to reason as tyrants who seek to rationalize their particular abuse as endemic to the nature of power and politics itself. But, if the whole point about emancipatory politics or praxis is that it exceeds what was thinkable, it does so, first, in a dialectical relationship to existent ideas and ideals, even if framed in the negative. This is what I mean by a regulative ideal: anticolonial struggle, in its initial moments, mobilizes an idea of the nation, which is more defensible than a country run for the benefit of foreign occupiers. If political participation is what makes a human being an adult, the argument continues, no one should be barred and one then opens the polity to the challenge of facilitating the different way of undertaking political life that must necessarily result. In other words, if most political ideals have only existed in compromised and contradictory form, in revolutionary action, these are reinvoked with the aim of more actually actualizing them. To say that emancipatory politics is mobilized around regulative ideals of what it is no longer to be enslaved or colonized is not to say that in it those mobilized don't experience what it is to be or become a sovereign people. There is no tension between these claims.

A dialectical reading would also mean that the realization of an actual general or creolizing will by one generation will inevitably be met by subsequent defeats. But politics is not only evident in the successful moment. Since, after all, what erupts positively and progressively only does so through considerable intermediary efforts and organizing. Through these efforts historical lessons that would be rendered invisible by those who would prefer they be forgotten are instead retold, rekindling the imagination of people who might otherwise believe that to think like anything other than a tyrant is naïve.

Journal of French and Francophone Philosophy | Revue de la philosophie française et de langue française Vol XXV, No 2 (2017) | http://www.jffp.org | DOI 10.5195/jffp.2017.825 
At the same time, I am under no illusions. In our world, states continue to act in kleptocratic and predatory ways, often increasing rather than counteracting the vulnerability of most citizens. Still, we know that they must work otherwise, even if we are not certain that they can. Ngũg ̃ wa Thiong'o captures this predicament beautifully in his many novels and critical essays. Sonia Dayan-Herzbrun couldn't be more accurate in her celebration of his effective creolization of Marxism: of Ngũgĩ's ability to grasp structural relations diagnosed by Marx, but in language that grabs you by the guts and that explores expropriation and alienation in the context of neocolonial life through sustained attention to language, to the distinct potential roles of women and men, and to different forms and natures of knowing. For instance, review the passage quoted in Dayan-Herzbrun's essay: "It is part of that struggle for that world in which my health is not dependent on another's leprosery; my cleanliness not on another's maggotridden body; and my humanity not on the buried humanity of others." Dayan-Herzbrun rightly emphasizes that it was in response to the persistent efforts of a young woman who insisted that Ngũgi teach outside of the academy, where in the Queen's English he served only the children of the Kenyan bourgeoisie, that brought him in direct and ongoing contact with ordinary people who enlarged his conception of political life and action.

This assessment of Ngũgĩ's contributions is exemplified especially well in his 2006 Wizard of the Crow, a book that explicitly explores the seemingly impossible through pitting a voraciously corrupt neocolonial class that will settle for nothing less than absolute rule against those whose resistant aims must be and are thoroughly creolizing. ${ }^{16}$ Consider the specifics: The Ruler, who remains nameless over the course of hundreds of pages, aims to consolidate complete control, insisting that the Country of Abruriria and he are referred to synonymously. His own self-aggrandizing version of contentious political events are "the news," while his prisons overflow with all variants of political dissidents. He regularly thins the ranks of his own citizens simply because he can. In one particularly extreme genuflecting moment, one of his ministers recommended that the Ruler be considered the author of any and everything that might be written or thought within the bounds of Abruriria. While everyone knows that the Ruler is sick, his pawns seek to divert attention from this obvious truth through announcing that plans are underway to erect a contemporary Tower of Babel that would triumph where biblical efforts had failed. Once finished, it would not only be the envy of the world, but would also put the Ruler in direct and ongoing contact with G-d-proximity G-d is assumed to welcome. What is more, anticipating the absurdities of the promises of the current president of the United States, it is announced that Banks of Europe and the United States would foot the bill! Despite the clear impossibility of the undertaking, the Ruler and his peons devote all their energies to this seemingly constructive activity.

Journal of French and Francophone Philosophy | Revue de la philosophie française et de langue française Vol XXV, No 2 (2017) | http://www.jffp.org | DOI 10.5195/jffp.2017.825 
In stark contrast to their illegitimacy, there are Kamiti and Nyawira, young adults seeking neither wealth nor dominion. He is an educated and thinking man who must seek employment from crooks and is plagued by an ability to smell the ethical character of people, most of whom, in being willing to be bought, literally stink. He can also sense possibility. He smells this first as a scent of flowers that Nyawira exudes. He is able to create his own occupation through creolizing the traditional role of sorcerer, in an environment in which none wish to admit that they all seek a piece of such power. Nyawira, however, as a true Fanonian, insists that one cannot heal individual people without mending their social world. This initially restorative politics must be one of unity that guides the deployment of force. It should grow from knowledge conceived as the discovery of magic within the ordinary and as emerging out of all people and from multiple places as a shared, collective asset. For Kamiti this involves continuing the legacy of cross-pollinating East Indian and East African traditions in an indigenous African politics that emerges through a dialogue with rather than subservient relationship to custodians of tradition. It must be built through more than relations of patronage in which some are always accruing indebtedness and instead nurture an infrastructure to enable citizens to take what they need with a duty to contribute what they can. The practical and romantic relationship and collaboration of Kamiti and Nyawira as portrayed in The Wizard of the Crow instantiates the possibility of combining a humanistic openness to resources of magic and spirituality with one that is primarily political. Their combined efforts culminate in tentative and gorgeous images of an alternative to what will be more of the same vampiric contempt for the future that institutionalizes terror to create situations that are ungovernable.

The text, then, offers insight into how a resistance movement that drew on the political mythos of Abruriria seized and made space within the vacuum created by necropolitical rule. In each instance, their performances demonstrated the shittiness of using a state solely as a means to advance one's own very narrow economic interests and demonstrated that alienated people who have determined not to tolerate the further abuse of what remains of their country can wield immense disruptive and potentially constructive power. The story also affirms that democratic theory must also be economic theory, that discussion of the kinds of practices that should constitute the former must also address the material conditions that are their prerequisite. In ways that have much resonance for contemporary residents of the United States, The Wizard of the Crow forces the reader to imagine mundane life in the heights and depths of political absurdity, in which the desires of a human being to be like a god dictate the fates and lives of millions. The Ruler's and his minister's strange and outlandish creativity is at times genuinely impressive, but it relies consistently on the disabling of all others. The story also illustrates the ongoing value of the idea of political legitimacy - it may seldom be embodied, but when it is, it is immediately

Journal of French and Francophone Philosophy | Revue de la philosophie française et de langue française

Vol XXV, No 2 (2017) | http://www.jffp.org | DOI 10.5195/jffp.2017.825 
recognized and affirmed without coercion. Of necessity, it is profoundly creolizing, emerging out of an ability to forge out of a fractured environment, a vision of how differently collective life might be led, not simply drawing from ideas and practices of discrete national communities but from distinct domains of life, often thought to be profoundly opposed.

In Rousseau's words, it would be reasoning as tyrants and in Fanon's it would be a failure to be adequately sociogenetic in our approach, if we assume that states must always function in the same way. As Boaventura de Sousa Santos has repeatedly pointed out: colonialism exploits and alienates in multiple, discrete ways so that effective counters to it must figure out how to speak among these idioms so that their complementarity does not only serve the already forceful. ${ }^{17}$ Creolization describes moments when this is achieved through collective efforts to grasp and then make material conditions that enable a more and more generalizing will, attentive always to those most prone to remain present only in their absences.

1 Jane Anna Gordon, Creolizing Political Theory: Reading Rousseau through Frantz Fanon (New York: Fordham University Press, 2014).

${ }^{2}$ Lewis R. Gordon, An Introduction to Africana Philosophy (London: Cambridge University Press, 2008).

${ }^{3}$ Penny Weiss, Canon Fodder: Historical Women Political Thinkers (College Park: Pennsylvania State University Press, 2009).

4 Angélica Maria Bernal, Beyond Origins: Rethinking Founding in a Time of Constitutional Democracy (New York: Oxford University Press, 2017); George Ciccariello-Maher, We Created Chavez: A People's History of the Venezuelan Revolution (Durham, NC: Duke University Press, 2013); Enrique Dussel, Twenty Theses on Politics (Durham, NC: Duke University Press, 2008); Katherine Gordy, Living Ideology in Cuba: Socialism in Principle and Practice (Ann Arbor: University of Michigan Press, 2015).

${ }^{5}$ Nathalie Etoke, Melancholia Africana: L'indispensable dépassment de la condition noire (Paris: Editions du Cygne, 2010).

${ }^{6}$ W.E.B. Du Bois, Souls of Black Folk (New York : Dover Thrift, 1994/1903) and Paget Henry, "Africana Phenomenology: Its Philosophical Implications" in Journeys in Caribbean Thought, eds. Jane Anna Gordon, Lewis R. Gordon, Aaron Kamugisha, and Neil Roberts (London: Rowman and Littlefield International, 2016): 27-58.

${ }^{7}$ Aimé Césaire, Discourse on Colonialism (New York: Monthly Review Press, 2001). 
${ }^{8}$ Patrick Wolfe, Traces of History: Elementary Structures of Race (London: Verso, 2016).

9 Sandy Grande, Red Pedagogy: Native American Social and Political Thought (Lanham, MD: Rowman and Littlefield Publishers, 2004).

10 Nathalie Etoke, Afro Diasporic French Identities, a 2012 film, available here: https: / / www.youtube.com/watch?v=bQcGNjGywSI.

11 W.E.B. DuBois, Black Reconstruction in America 1860-1880 (New York: The Free Press, 1992/1935).

12 Jane Anna Gordon and Keisha Lindsay, "Black On Red: 19th Century African American Interpretative Uses of Native American Political Experience," presented at the Western Political Science Association Annual Conference, Vancouver 2017.

13 Kevin Bruyneel, The Third Space of Sovereignty: The Post-Colonial Politics of U.S.-Indigenous Relations (Minneapolis: University of Minnesota Press, 2007) and "Finding White Settler-ness: Settler Memory and U.S. Race Discourse and Politics," presented at the Western Political Science Association Annual Conference, Vancouver, 2017; Glen Sean Coulthard, Red Skin, White Masks: Rejecting the Colonial Politics of Recognition (Minneapolis: University of Minnesota Press, 2014) and "Postcolonialism and Political Theory," presented at the American Political Science Association Annual Conference, San Francisco, 2017; Vine Deloria, Jr. Custer Died for Your Sins: An Indian Manifesto (Norman: University of Oklahoma Press, 1969); George Manuel and Michael Posluns, The Fourth World: An Indian Reality (Don Mills, Ontario: Collier-Macmillan Canada, 1974).

${ }^{14}$ Lewis R. Gordon, What Fanon Said (New York: Fordham University Press, 2015), 116-117.

15 Julia Suárez-Krabbe, Race, Rights and Rebels: Alternatives to Human Rights and Development from the Global South (London: Rowman and Littlefield International, 2016).

${ }^{16}$ Ngũgĩ wa Thiong'o, The Wizard of the Crow, (New York: Pantheon Books, 2006).

17 Boaventura de Sousa Santos, Epistemologies of the South: Justice against Epistemicide (New York: Taylor and Francis, 2014).

Journal of French and Francophone Philosophy | Revue de la philosophie française et de langue française Vol XXV, No 2 (2017) | http://www.jffp.org | DOI 10.5195/jffp.2017.825 